\title{
HAK PEMANFAATAN SUMBER DAYA ALAM PERSPEKTIF HUKUM ISLAM
}

\author{
Mugiyati $\mid$ Univeritas Islam N egeri Sunan \\ Mugiyati.supel@yahoo.co.id A mpel Jl. A. Ayni 117 Surabaya
}

\begin{abstract}
Islam gives freedom to people to utilize the public natural reso urces, because everyone has the irtifâq right namely to use immovable good, whether it belongs to an individual or public property. Common ownership is allowed in Islamic law if an object which is intended and used for the public. The principle of freedom granted by Islam for the right holders to use is not without limit, but constrained by accountability and adherence to sharia. The right holders in using theirs' is to be in line with the principle of maqâshid al-syarîah. $0 \mathrm{n}$ the basis of this principle, they are prohibited to use their rights in excess which lead to infringement and damages to the interests of the others as well as the rights and interests of the general public. $0 \mathrm{f}$ course, this can be jailed (ta'zîr) by the jud ge.

Keyword s: Right holder, natural resources, Islamic law.
\end{abstract}

Abstrak: Islam memberikan kebebasan kepada manusia untuk memanfaatkan sumber daya alam yang bersifat publik, karena setiap orang memiliki hak irtifâq yaitu hak pemanfaatan benda tidak bergerak, baik benda itu milik individu atau milik umum". Kepemilikan umum dimungkinkan dalam hukum Islam jika suatu benda pemanfaatannya diperuntukan bagi masyarakat umum yang mana masing-masing saling membutuhkan. Prinsip kebebasan yang diberikan Islam bagi pemilik hak untuk mempergunakan haknya bukanlah bebas tanpa batas, namun dibatasi oleh pertanggungjawaban dan kepatuhan pada syariah. Pemegang hak dalam menggunakan haknya harus sejalan dengan maqâshid al-syarî'ah. Atas dasar prinsip ini pemilik hak dilarang mempergunakan haknya secara berlebihan yang menimbulkan pelanggaran hak dan kerugian terhadap kepentingan orang lain maupun terhadap hak dan kepentingan masyarakat umum dan dapat dikenai hukuman penjara (ta'zîr) oleh hakim.

Kata Kunci: Hak pemanfaatan, sumber daya alam, hukum Islam. 


\section{Pendahuluan}

Problem lingkungan yang kini dihadapi umat manusia umumnya disebabkan oleh dua hal: Pertama, kejadian alam sebagai peristiwa yang harus terjadi sebagai akibat proses dinamika alam. Kedua, peristiwa yang diakibatkan oleh perbuatan manusia. Kedua bentuk kejadian di atas bisa jadi mengakibatkan ketidakseimbangan pada ekosistem dan ketidak nyamanan kehidupan makhluk hidup baik manusia, tumbuh-tumbuhan maupun hewan. Ketidak seimbangan dan ketidaknyamanan tersebut dalam kadar tertentu dapat dikatakan sebagai bencana.

Masalah lingkungan akan timbul dari adanya interaksi antara aktivitas ekonomi manusia dan sumber daya alam, yang berawal dari adanya permintaan masyarakat akan barang dan jasa, selanjutnya mengakibatkan meningkatnya permintaan sumber daya alam. M elalui kegiatan ekonomi, sumber daya alam yang semakin meningkat dan dilakukan terus menerus tanpa diikuti oleh usaha lain untuk melestarikannya maka daya dukung lingkungan akan menjadi berkurang. Dahuri menyebutkan bahwa kebutuhan manusia yang semakin meningkat, sementara daya dukung alam bersifat terbatas menyebabkan potensi kerusakan sumberdaya alam menjadi semakin besar. $\mathrm{H}$ al ini tentunya memberikan dampak yang cukup serius bagi kelangsungan hidup masyarakat. ${ }^{1}$

Sebagai pelaku sejarah, manusia seringkali yang paling bertanggung jawab dalam konservasi alam dan kelestarian ekologi. ${ }^{2}$ Para ahli terus melacak penyebab utama dari kerusakan alam. Sebagian yang lain menyimpulkan bahwa kerusakan lingkungan merupakan akibat sikap dan pandangan (word view) yang menyimpang dari falsafat kehidupan dan keagamaan. ${ }^{3}$

Secara prinsip I slam tidak melarang manusia untuk memanfaatkan kekayaan alam yang telah Allah swt sediakan untuk manusia sebagaimana yang telah dimanifestasikan dalam Q S. al-H ijr ayat 19-20 berikut ini:

\footnotetext{
${ }^{1}$ Rokhmin Dahuri, dkk, Pengelolaan Sumber Daya A lam (Jakarta: PT Pradnya Paramita, 2004),

${ }^{2}$ Ekologi adalah ilmu yang mempelajari hubungan timbal balik antara makhluk hidup dengan lingkungannya. Kata ekologi diperkenalkan oleh Ernest Haekel, ahli biologi Jerman pada tahun 1869, terdiri dari kata "oikos" yang berarti rumah atau tempat tinggal dan "logos" yang berarti telaah atau studi. Lihat Resosoedarmo. S. dkk., Pengantar Ekologi (Jakarta: Fakulktas Pascasarjana IKIP, 1985), 1.

${ }^{3}$ Ali Yafie, Merintis Fiqin Lingkungan Hidup (Jakarta: UFUK Press, 2006), 42. Lihat juga Alwi Shihab, Islam Inklusif (Bandung; Mizan, 1998), 158.
} 
Dan Kami telah menghamparkan bumi, dan Kami menjadikan padanya gunung-gunung, serta Kami tumbuhkan di sana segala sesuatu menurut ukuran. Dan Kami telah menjadikan padanya sumber-sumber kehidupan, untuk keperluanmu, dan (Kami ciptakan pula) makhluk-makhluk yang bukan kamu pemberi rezekinya. ${ }^{4}$

Lingkungan hidup sebagai sumber daya yang dapat dimanfaatkan oleh manusia guna memenuhi kebutuhan hidupnya ditegaskan kembali oleh Allah swt dalam firmanN ya:

Dialah yang menjadikan bumi itu mudah bagi kamu, maka berjalanlah di segala penjurunya, dan makanlah sebagian dari rizki-N ya. Dan hanya kepada-N ya lah kamu (kembali setelah) dibangkitkan." (Q S. Al-M ulk: 15)

Lingkungan hidup sebagai sumber daya mempunyai regenerasi dan asimilasi yang terbatas selama eksploitasi atau penggunaannya dibawah batas daya regenerasi atau asimilasi, maka sumber daya terbaharui dapat digunakan secara lestari. Akan tetapi apabila batas itu dilampaui, sumber daya akan mengalami kerusakan dan fungsinya sebagai faktor produksi dan konsumsi atau sarana pelayanan akan mengalami gangguan. ${ }^{6}$ Sehingga manusia mempunyai tanggung jawab untuk memelihara dan memakmurkan alam sekitarnya serta menjaganya tetap lestari karena membuat kerusakan terhadap alam semesta dinilai sebagai sebuah kejahatan sebagaimana dinyatakan dalam alquran surat asy-Syu'ara' ayat 183:

D an janganlah kamu merugikan manusia pada hak-haknya dan janganlah kamu merajalela di muka bumi dengan membuat kerusakan. $^{7}$

Di dalam UU No 23 Tahun 1997 memuat ketentuan hak setiap orang atas lingkungan yang baik dan sehat, berarti kewajiban bagi setiap orang untuk memelihara kemampuan lingkungan hidup agar tetap dimanfaatkan untuk perlindungan dan kebutuhan manusia atau makhluk hidup lainnya, termasuk juga upaya mencegah dan menanggulangi perusakan lingkungan. Dalam undang-undang itu pula

\footnotetext{
${ }^{4}$ Departemen A gama, Al-Q ur'an dan T erjemahnya ( Jakarta: Departemen A gama, 1997), 264.

${ }^{5} \mathrm{Ibid},{ }_{6} 64$.

${ }^{6} 0$ tto So emarwoto, Ekologi, Lingkungan Hidup dan Pembangunan (Jakarta: Djambatan, 1997), 59.

${ }^{7}$ Departemen Agama, al-Q ur'an dan Terjemahnya..,.
} 
dengan adanya hak dan kewajiban tersebut melahirkan pertanggungjawaban perdata maupun sanksi pidana. Sanksi ini sudah cukup memadai untuk diterapkan pada pelaku perusakan maupun pencemaran yang disinyalir saat ini sudah banyak terjadi.

Berbagai isu, benturan kepentingan para pihak dan konflik hak yang terjadi dalam aktivitas pemanfaatan sumber daya alam oleh masyarakat penting menjadi bahan kajian hukum Islam dan sudah seharusnya menjadi perhatian berbagai pihak dari segala lapisan termasuk kalangan akademisi. Bukan hanya menjadi tanggung jawab pemerintah saja. Karena itu, sudah saatnya dipikirkan upaya keterlibatan masyarakat dalam upaya-upaya pengendalian pencemaran, pengawasan, penyelesaian konflik serta pengelolaan sumber daya alam.

\section{H ak Kebendaan (al-Huqûq)}

Secara epistimologi, "al-haq" mempunyai beberapa pengertian yang berbeda, di antaranya berarti ketetapan atau kepastian. Dalam terminologi figh, terdapat beberapa pengertian al-haq ${ }^{8}$ yang dikemukakan para ulama figh. D i antaranya adalah: ${ }^{9}$

"H ak adalah kewenangan atas atas sesuatu, atau sesuatu yang

wajib atas seseorang untuk orang lain".

Berdasarkan definisi tersebut, terdapat dua substansi hak: Pertama, hak sebagai "kewenangan atas sesuatu/barang" yakni hak yang berlaku atas benda (disebut haq 'aini) seperti hak milik (milkiyah) hak penguasaan atas benda dan sebagainya. Kedua, hak sebagai keharusan atau kewajiban pada pihak lain. Substansi hak yang terbebankan pada orang lain (disebut haq syakhshiy) ini dapat dipahami sebagai taklif baik yang bersumber dari syara' seperti hak istri yang terbebankan pada suami, hak anak yang terbebankan pada orang tua dan lain sebagainya. $M$ aupun yang bersumber dari akad seperti hak buruh atas upah, hak pelunasan hutang, hak yang timbul dari akad jual beli, sewa menyewa dan lain-lain.

Menurut Wahbah Zuhayly "Hak adalah suatu khususan (ikhtishâsh) yang dengannya syara' menetapkan kewenangan atau otoritas (as-sulthah) dan beban (taklif)". Jika dikaitkan dengan definisi tersebut, maka term intishâsh (kekhususan) yang dimaksud dalam

\footnotetext{
${ }^{8}$ Selanjutnya ditulis dengan ejakan "hak"

${ }^{9}$ Ghufron A. M as'adi, Fiqh M uamalah Kontekstual (Jakarta: Raja Grafindo Persada, 2002), 33.
} 
definisi yang tersebut dengan sendirinya telah mencakup dua hal, yaitu kewenangan atas sesuatu (al-sulthah 'ala al-syay') dan keharusan kepada seseorang (al-taklîf 'alâ syakhsh). Kedua kekhususan tersebut bersumber dari syara' (ketetapan Allah yang di dalam bahasa sosiologi dapat juga berarti aturan hukum atas dasar kesepakatan bersama). ${ }^{10}$

\section{Akibat $\mathrm{H}$ ukum Suatu $\mathrm{H}$ ak}

Para fuqaha mengemukakan beberapa akibat hukum yang berkaitan dengan adanya suatu hak, yaitu:

a. Perlindungan $\mathrm{H}$ ak

Pada prinsipnya, Islam memberikan jaminan perlindungan hak setiap orang. Setiap orang boleh menuntut pemenuhan haknya. A pabila terjadi pelanggaran atau pengerusakan hak maka pemilik hak dapat menuntut ganti rugi/denda yang sepadan dengan haknya. A pabila terjadi perselisihan dalam pemenuhan hak maka pihak pemerintah atau hakim wajib memaksa pihak tertentu agar memenuhi hak orang lain.

Perlindungan hak dalam ajaran Islam merupakan penjabaran dari ajaran dan prinsip keadilan. D emi keadilan diperlukan kekuatan atau kekuasaan untuk melindungi dan menjamin terpeliharanya hak tanpa jaminan seperti ini. Pelanggaran dan pelecehan hak orang lain berkembang pesat. ${ }^{11}$

b. Pelaksanaan dan Penuntutan $\mathrm{H}$ ak

Para pemilik hak harus melaksanakan hak-haknya itu dengan cara-cara yang disyari'atkan. Dalam persoalan hak Allah yang berkaitan dengan persoalan ibadah, seseorang harus menunaikannya sesuai dengan ketentuan-ketentuan Allah. Apabila seseorang tidak mau melaksanakan hak Allah tersebut dan hak itu berkaitan dengan persoalan harta, seperti zakat maka hakim (penguasa) berhak untuk memaksanya menunaikan zakat.

$\mathrm{H}$ ak manusia pelaksanaannya dilakukan dengan cara mengambilnya dan membayarkannya kepada orang yang berhak menerimanya (pemilik hak). M isalnya, jika seseorang mencuri harta orang lain, maka pencurian itu harus mengembalikan harta itu jika masih untuh atau menggantinya degan harga yang sepadan/senilai

\footnotetext{
10 lbid., 34.
}

${ }^{11}$ lbid., 37. 
dengan harta tersebut, jika harta yang dicuri sudah tidak untuh lagi. yang terpenting dalam kasus seperti ini, menurut para ulama figh adalah sifat keadilan dalam pengembalian hak, sehingga masingmasing pihak tidak ada yang dirugikan.

c. Pemeliharaan $\mathrm{H}$ ak

Syari'at Islam telah menetapkan bahwa setiap orang berhak untuk memelihara dan menjaga haknya dari segala bentuk kesewenangan pihak lain, baik yang menyangkut hak kepidanaan maupun hak keperdataan. A pabila harta seseorang dirampas, maka ia berhak menuntut secara pidana dan secara perdata. Tuntutan secara pidana dilakukan untuk melaksanakan hukuman potong tangan, sedangkan gugatan perdata dilakukan untuk menggugat agar harta yang dirampas dapat dikembalikan jika masih utuk dan mengganti yang senilai dengan harta yang dirampas jika harta tersebut telah habis.

d. Penggunaan $\mathrm{H}$ ak

Pada prinsipnya, Islam memberikan kebebasan bagi setiap pemilik hak untuk mempergunakan haknya sesuai dengan kehendaknya, sepanjang tidak bertentangan dengan syariat Islam. Atas dasar prinsip ini pemilik hak dilarang mempergunakan haknya untuk hal-hal yang dilarang oleh syara', seperti menggunakan hak tetapi pelaksanaannya merusak lingkungan atau alam.

Kebebasan menggunakan hak selain dibatasi dengan "tidak bertentangan syara'" juga dibatasi oleh "tidak melanggar hak atau merugikan orang lain". Prinsip perlindungan hak dalam Islam sebagaimana telah disebutkan sebelumnya, berlaku pada dan untuk semua orang. Sehingga perlindungan dan kebebasan dalam penggunaan hak pribadi harus sejalan dan seimbang dengan perlindungan hak orang lain, terutama perlindungan hak masyarakat umum.

Penggunaan hak secara berlebihan yang menimbulkan pelanggaran hak dan kerugian terhadap kepentingan orang lain maupun terhadap hak dan kepentingan masyarakat umum dalam hukum Islam disebut ta'assul fi isti'mâl al-haq (sewenang-wenang dalam penggunaan hak) apabila seseorang menggunakan suatu yang 
bukan haknya, tidak dinamakan ta'assul fi isti'mâl al-haq, tetapi disebut dengan ta'addiy. ${ }^{12}$

Menurut para fuqaha keharaman ta'assul fi isti'mâl al-haq disebabkan oleh dua hal: ${ }^{13}$

a. Setiap orang tidak boleh menggunakan haknya dengan sewenangwenang, sehingga membawa madharat bagi orang lain. O leh sebab itu, penggunaan hak dalam syari'at I slam tidak bersifat muthlak, tetapi dibatasi, batasannya adalah tidak membawa madharat kepada pihak lain, baik perorangan maupun masyarakat.

b. Penggunaan hak-hak pribadi tidak hanya untuk kepentingan pribadi belaka, tetapi juga harus mendukung hak-hak masyarakat, karena kekayaan yang dimiliki seseorang merupakan bagian dari kekayaan seluruh manusia. Bahkan dalam keadaan tertentu hakhak pribadi boleh diambil atau dikurangi untuk membantu hakhak masyarakat, seperti pengambilan zakat, pajak, shadaqah dan lainnya.

W ahbah Zuhayly menggolongkan beberapa bentuk perbuatan yang termasuk kedalam ta'assul fi isti'mâl al-haq, yaitu: (1) Apabila seseorang dalam mempergunakan haknya mengakibatkan pelanggaran terhadap hak orang lain atau menimbulkan kerugian terhadap kepentingan orang lain, maka perbuatan itu merupakan perbuatan sewenang-wenang dan hukumnya haram. A tas tindakan ini, menurut para fuqaha dapat dikenai hukuman ta'zîr oleh hakim. (2) M elaksanakan suatu tindakan yang tidak disyari'atkan. A pabila seseorang melakukan suatu perbuatan yang tidak disyari'atkan dan tidak sesuai dengan kemaslahatan yang ingin dicapai dalam penggunaan hak itu, maka tindakannya harus dicegah. (3) M unculnya kemudharatan yang yang lebih besar ketika menggunakan hak untuk mencapai suatu kemaslahatan. (4) Penggunaan hak tidak pada tempatnya, atau bertentangan dengan adat kebiasaan yang berlaku serta menimbulkan madharat terhadap pihak lain. (5) Menggunakan hak dengan tindakan yang lalai atau ceroboh sehingga mengakibatkan madharat terhadap pihak lain, maka tindakan itu termasuk ta'assul fi isti'mâl al-haq yang dilarang syara'.

\footnotetext{
${ }^{12}$ W ahbah al-Zuhayly, al-Fiqh al-Islâmiy wa A dillatuhu, Juz. 4, 29.

${ }^{13}$ Fathi ad-Duraini, at- Ta'assul fi Isti'mâl al-Haq (Beirut: M uassasah ar-Risalah, 1977), 60.
} 


\section{M acam-M acam $\mathrm{H}$ ak}

H ukum Islam secara garis besar membedakan hak menjadi dua: Pertama: $\mathrm{H}$ aq al-mâliy, yakni hak yang berkaitan dengan harta benda, seperti hak kepemilikan benda (hak milkiyah). Kedua, haq ghairu milkiyah, yakni hak yang tidak berkaitan dengan harta benda, seperti hak seorang wali terhadap pemeliharaan anak kecil.

Adapun obyek pembahasan hak yang berkaitan dengan hak-hak kebendaan terbagi menjadi beberapa bagian ditinjau dari berbagai segi:

a. Bentuk hak ditinjau dari segi pemiliknya atau dari segi sifat pemanfaatannya apakah mencakup keseluruhan manusia atau tidak, hak dibedakan menjadi "hak Allah dan hak manusia".

1. Hak Allah

$\mathrm{H}$ ak Allah adalah hak yang kemanfaatannya ditujukan untuk melindungi kepentingan umum (mashlahah al-ummah). $\mathrm{H}$ al ini disandarkan dengan asma Allah karena kemanfaatannya yang sangat besar untuk melindungi kepentingan publik. Segala bentuk peribadatan dalam Islam, dan segala bentuk aturan untuk melindungi ketertiban umum seperti aturan sanksi pidana tergolong hak Allah. ${ }^{14}$ Berikut beberapa macam hak Allah: $:^{15}$ (1) Ibadah murni seperti iman kepada Allah, shalat, puasa dan sebagainya. (2) Hukuman murni seperti hak "had" (hukuman) pencuri, pezina dan lain-lain. (3) Hukuman terbatas seperti hilangnya hak mewarisi dari harta orang yang dibunuh bagi pembunuh. (4) Ibadah yang mengeluarkan harta benda seperti zakat dan haji. (5) Pengeluaran harta benda yang mempunyai nilai ibadah seperti "al-U syr" (pengeluaran ${ }^{1} / 10$ penghasilan tanah). (6) Pengeluaran harta benda yang mempunyai hukuman seperti "alKharâj" (pajak tanah). (7) H ak asli yang tidak tergantung kepada suatu kewajiban yang harus ditunaikan seperti menyerahkan $1 / 5$ ghanimah (rampasan perang). Jihad adalah hak Allah, tetapi Allah memberikan $4 / 5$ nya kepada permujahidin sebagai karunia.

2. Hak Manusia

$\mathrm{H}$ ak manusia adalah hak yang ditujukan untuk melindungi kepentingan manusia secara individu sebagai pemilik hak. Contoh

\footnotetext{
${ }^{14}$ W ahbah al-Zuhayly, al-Fiqh al-Islâmiy... , Juz 4, 13.

${ }^{15}$ A bdurrazaq as-Sunburi, M ashâdir al-Haq fi al-Fiqh al-Islâmiy, Jilid I (t.t.p: Dirasatul Arabiyah, t.t), 44.
} 
hak manusia yang paling penting adalah milkiyyah (hak milik). Pelanggaran terhadap hak-hak manusia ini, hukumannya bersifat: (1) Adanya pemaafan, pembebasan/pengguguran dan perdamaian dari pihak-pihak yang bersangkutan. (2) Hak penuntutan kepada pihak korban atau walinya. (3) Tidak berlaku sistem "atTadakhul" yaitu hukuman dapat bertambah apabila perbuatan pidana berulang. (4) Hukuman budak sama dengan hukuman orang merdeka. (5) Berlaku cara turun temurun/dapat dapat diwariskan dari pihak yang kena korban. Selain pembagian dua jenis hak di atas, kebanyakan dalam kitab fiqh terdapat jenis hak ketiga yaitu hak berserikat/campuran antara hak Allah dan hak manusia. Jenis hak ini secara konseptual dapat dipahami sebagai sebuah hak yang pada satu sisi ditujukan untuk melindungi kepentingan publik sekaligus melindungi kepentingan pribadi. Jika demikian maka seesungguhnya pada setiap hak Allah terdapat juga perlindungan kepentingan pribadi, dan pada setiap hak manusia terdapat juga perlindungan terhadap kepentingan umum. Karena sesungguhnya antara dua kepentingan tersebut tidak dapat dipisahkan, dan perlindungan terhadap salah satu diantara kedua kepentingan tersebut mengandung perlindungan kepentingan lainnya. Namun kenyataannya hak Allah dan hak manusia, sekalipun saling terkait, keduanya merupakan hak yang masingmasing mempunyai sifat berbeda sehingga sangat sulit dibayangkan kedua jenis hak yang berbeda ini bersatu atau berserikat. Kenyataan yang terjadi bukan persekutuan dua hak melainkan persekutuan kasus. Artinya pada suatu kasus terjadi pelanggaran dua hak sekaligus. M isalnya pada kasus pencurian terjadi pelanggaran hak Allah (larangan mencuri untuk menjaga ketertiban umum), sehingga sanksi pidana pencurian tidak dapat digugurkan atau dimaafkan. Pada sisi lain terjadi pelanggaran terhadap hak manusia, yaitu hak milik kebendaan. Pemilik hak ini dapat menggugurkan hak menuntut kerugian atas denda melalui permaafan atau perdamaian.

b. Ditinjau dari segi substansinya hak dibedakan menjadi hak Syahshi (hak atas orang) dan hak 'ainiy (hak atas benda). Pembagian hak dari sisi substansinya ini tersirat dalam pengertian hak yaitu kewenangan 
atas sesuatu (hak 'ainiy) atau suatu keharusan atas seseorang untuk kepentingan orang lain (hak syahshi).

1. Hak Syakhshiy

$\mathrm{H}$ ak Syakhshiy adalah: "Suatu keharusan yang ditetapkan oleh syara' terhadap seseorang (pribadi) untuk kepentingan orang (pribadi) lainnya". ${ }^{16} \mathrm{D}$ alam hak syahshi terdapat dua pihak yang saling berinteraksi/berhubungan. Pertama adalah pihak yang mempunyai kewajiban (multazim) yang dalam akad mu'awwadhah ia sekaligus mempunyai hak atas pihak lain sebagai imbangan atas kewajiban yang dibebankan kepadanya. Seperti dalam akad jual beli, dimana pihak penjual mempunyai hak atas harga terhadap barang yang wajib ia serahkan kepada pihak pembeli, demikian pula sebaliknya pembeli berhak atas barang yang diserahkan pihak penjual setelah ia menunaikan kewajibannya menyerahkan harga/tsaman kepada penjual. Kedua, kewenangan (al-sulthah) dan keistimewaan (ikhtishâh) atas benda secara langsung. bukan berarti benda tersebut dalam kekuasaannya, tetapi bisa jadi benda tersebut pada kenyataannya berada dalam kekuasaan orang lain, seperti pada akad wadî'ah, ijârah (sewa menyewa) atau benda yang disita dari kepentingan proses hukum. Sekalipun demikian kekuasaan pemilik benda tetap diakui secara hukum sebagai kekuasaan langsung. Berbeda dengan kekuasaan seorang penyewa atau orang yang menerima wadî'ah. Kekuasaan atas benda seperti ini bersifat tidak langsung karena melalui akad penguasaan yang bersifat sementara atau melalui penyerahan kekuasaan yang bersifat terbatas.

2. Hak 'Ainiy

$\mathrm{H}$ ak 'ainiy adalah kewenangan (al-sulthah) dan keistimewaan (al-ikhtishâsh) yang timbul karena hubungan antara seseorang dengan benda tertentu secara langsung. ${ }^{17} \mathrm{M}$ isalnya hak 'ainiy yang utama adalah hak milik (milkiyah). Seorang pemilik benda mempunyai kewenangan dan kekuasaan secara langsung (otomatis) atas harta benda yang dimilikinya. Ia memiliki kewenangan untuk memanfaatkan barangnya sesuai dengan

\footnotetext{
${ }^{16}$ W ahbah al-Zuhayliy, al-Fiqh al-Islâmiy... ., Juz 4, 19.

${ }^{17}$ M ustafa A hmad al-Zarqa', al-M adkhal al-Fiqh al-Âmm, Juz III (Beirut: Dar al-Fikri tt.), 17.
} 
kehendaknya, dan memiliki kekuasaan untuk menghalangi orang lain memanfaatkan tanpa seizin pemiliknya.

Berhubungan dengan hak 'ainiy ini terdapat dua hal yang perlu diperhatikan: (1) Obyek hak 'ainiy harus berupa benda konkrit sehingga pemilik benda mempunyai kekuasaan langsung atasnya tanpa melalui perantara pihak lain. Apabila obyeknya tidak konkrit, seperti pada akad jual beli saham, maka obyek hak yang dimiliki berupa tanggungan atau hutang belum merupakan benda konkrit. O leh karena itu hak pembeli tersebut sebagai hak syahshi bukan hak 'ainiy. (2) Kekuasaan langsung atas suatu benda yang pemilik hak bukan berarti bahwa benda tersebut selalu berada di tangannya. Tetapi mungkin pula bahwa benda tersebut kenyataannya dikuasai pihak lain, baik karena akad yang dibenarkan syara' seperti pada akad wadî'ah (titipan), di mana benda-benda di tangan orang yang dititipi, maupun karena perbuatan melanggar hukum seperti perampasan dan pencurian. M eskipun demikian hak kepemilikan atas benda tetap berada pada pihak asli benda tersebut. Dalam figh hak 'ainiy memiliki beberapa bentuk sebagai berikut;

1. H aq al-Intifấ'

Secara etimologi, al-intifâ' berarti "menggunakan, memanfaatkan atau memakai". Secara terminologi haq al-intifâ' yaitu kewenangan memanfaatkan sesuatu yang berada dalam kekuasaan atau milik orang lain, dan kewenangan tersebut terjadi disebabkan oleh hal yang dibenarkan oleh syara'. H aq al-intifâ' disebut juga dengan milk al-manfa'ah asy-syakhshiy (pemilikan manfaat pribadi ). W ahbah Zuhaily mencatat lima sebab yang menimbulkan haq al-intifâ': melalui i'ârah, ijârah, wakaf, washiyyah bi al-manfa'ah dan ibâhah. ${ }^{18}$

2. H aq al-Irtifâq

Secara etimologi, irtifâq berarti "pemanfaatan sesuatu". $\mathrm{H}$ aq al-irtifâq disebut juga dengan "milk al-manfa'ah al-'ainiy (pemilikan manfaat suatu benda). Pemanfataan yang dimaksud adalah pemanfaatan benda tidak bergerak (tetap), baik benda itu milik individu tertentu maupun benda milik kolektif (umum ). Secara terminologi, para fuqaha mendefinisikan haq

${ }^{18}$ W ahbah Zuhayily, al-Fiqh al-Islâmiy, juz. 4, 67. 
al-irtifâq sebagai berikut: "Hak pemanfaatan benda tidak bergerak, baik benda itu milik individu atau milik umum".

$\mathrm{H}$ ak al-irtifâq timbul karena sebab-sebab sebagai berikut: ${ }^{19}$ (1) Karena ketetapan syara', atau karena undang-undang seperti pembebasan tanah hak milik untuk kepentingan umum, penguasaan negara atas hak milik untuk fasilitas umum seperti untuk pasar, sekolah dan lain sebagainya. (2) Disebabkan perserikatan umum atau menurut pembentukannya benda tersebut diperuntukkan untuk kepentingan umum seperti jalan raya dan sungai. (3) D isebabkan adanya perjanjian atau syarat yang disepakati ketika melakukan suatu transaksi, seperti penjual mensyaratkan bahwa ia berhak untuk melewati di atas lahan yang telah dijualnya kepada pembeli.

Menurut Jumhur ulama bahwa haq al-irtifâq tidak terbatas jumlahnya, oleh karena itu sangat dimungkinkan muncul berbagai bentuk haq al-irtifâq baru sesuai dengan kebutuhan. Sedangkan menurut $\mathrm{H}$ anafiyah terdapat enam macam haq al-irtifâq yang pokok, yaitu; haq al-syurb (hak mengambil air untuk minum), haq al-majrâ (hak mengalirkan air di lahan orang lain), haq al-masil (hak mengalirkan pembuangan melalui selokan), haq ath-tharîq (hak melewati di lahan orang lain), haq al-jiwâr (hak jiran yang berdampingan rumah ), haq at-ta'âliy (hak tinggal di atas rumah orang lain):

a. $\mathrm{H}$ aq al-Syurb

Yaitu hak seseorang untuk mengairi tanaman, termasuk hak manusia dan hewan untuk memanfaatkan air. Dalam lingkup haq al-syurb para ulama mengelompokkan macam air menjadi: (a) air yang ditampung dalam tempat khusus oleh pemiliknya, (b) air sumur, (c) air sungai yang melintasi lahan pribadi tertentu atau pengairan yang dibuat oleh seseorang/kelompok tertentu dan (d) air sungai besar. ${ }^{20}$ Pengklasifikasian tersebut memberikan implikasi hukum sebagai berikut:

(1) Terhadap air yang ditampung secara khusus oleh pemiliknya, maka haq al-irtifâq baru berlaku apabila

${ }^{19}$ Ibid., 68.

${ }^{20}$ Al-Kasani, Badâ'I' ash-Shanâi', jilid VI, (Beirut: Dar Gharb al-Islamiy, t.t.), 188. 
pemiliknya memberi izin untuk dimanfaatkan. Air yang termasuk dalam kelompok ini dapat diperjualbelikan oleh pemiliknya.

(2) Terhadap air sumur atau kolam, menurut ulama Jumhur non $\mathrm{H}$ anafi bahwa jika sumur itu digali oleh seseorang, baik di lahannya sendiri maupun di lahan kosong, maka sumur itu menjadi miliknya. Oleh karena itu, bagi pemilik sumur tidak ada keharusan untuk memberi izin kepada orang lain memanfaatkan air itu, karena biaya pemeliharaannya menjadi tanggungan pemiliknya.

(3) Air sungai khusus yang dibuat dan dimiliki oleh sekelompok orang, hukumnya sama sebagaimana terhadap air sumur.

(4) Ulama figh sepakat menyatakan bahwa air sungai yang secara alami terbentuk tidak dapat menjadi milik pribadi atau sekelompok tertentu. Sehingga boleh dimanfaatkan oleh siapa saja yang membutuhkannya, baik untuk kepentingan pribadi, ternak maupun untuk mengairi tanaman. Namun jika pemanfaatannya menimbulkan kemadharatan terhadap orang lain maupun terhadap sungai itu sendiri, maka setiap orang boleh melarangnya atau membatasinya. Adapun biaya pemeliharaan sungai tersebut dibebankan pada negara.

b. H aq al-M ajrâ

$\mathrm{H}$ aq al-majrâ merupakan hak mengalirkan air bagi pemilik lahan yang jauh dari aliran irigasi untuk mengairi lahannya melalui lahan orang lain. Prinsip umum yang berlaku dalam hal ini adalah bahwa pemilik lahan yang dekat dengan sumber air tidak boleh melarang pemilik lahan yang jauh dari sumber air untuk mengalirkan air ke lahannya, meskipun harus membuat aliran air melalui lahan orang yang dekat dengan sumber air itu.

c. H aq al-M asil

$\mathrm{H}$ aq al-masil adalah hak untuk menyalurkan air pembuangan rumah tangga (selokan) ke penampungan atau saluran umum dengan mempergunakan saluran melintasi lahan orang lain. Pemanfaatan hak ini tidak boleh 
mengganggu kemaslahatan orang lain. Pemilik hak harus memelihara agar air kotornya tidak menyebar ke tempat lain.

d. H aq ath-Tharîq/H aq al-M urûr

Yaitu hak seseorang untuk sampai ke rumahnya dengan melewati lahan orang lain, baik lahan itu milik umum maupun lahan milik pribadi. Apabila jalan yang dilewati adalah jalan raya, maka setiap orang boleh melewatinya, berjualan di pinggir jalan itu atau parkir dengan syarat tidak memberikan madharat bagi orang lain dan harus seizin penguasa.

e. H aq at-T a'âliy

Adalah hak untuk tinggal di lantai atas pada perumahan bertingkat (rumah susun) dan menjadikan loteng rumah orang di tingkat bawah sebagai lantainya. $\mathrm{H}$ ak ini merupakan hak pemilik apartemen/rumah susun lantai atas. $M$ enurut Abu $\mathrm{H}$ anifah dan $\mathrm{M}$ aliki $\mathrm{H}$ ak ini akan tetap ada, sekalipun rumah lantai bawah sudah diruntuhkan, karena loteng itu tidak boleh diganggu gugat oleh pemilik lantai bawah; meskipun itu miliknyya.

f. H aq al-j iwâr

Yaitu hak jiran bersebelahan yang dinding mereka menyatu atau karena disebabkan saling bertemunya batas milik masing-masing. Para ulama menyatakan bahwa dalam kondisi seperti ini, masing-masing pemilik boleh memanfaatkan milik jirannya, selama tidak membawa madharat pada jiran tersebut. M isalnya, masing-masing pihak boleh mempergunakan dinding itu seperti menggantungkan lukisan atau pemasangan instalasi listrik, dengan syarat masing-masing pihak tidak mengganggu pihak lain.

\section{H ak Kepemilikan Sumber D aya Alam}

$\mathrm{H}$ ak milik juga merupakan hubungan antara manusia dengan harta yang ditetapkan oleh syara', di mana manusia memiliki kewenangan khusus untuk melakukan transaksi terhadap harta tersebut, sepanjang tidak ditemukan hal yang melarangnya. Secara terminology, al-milk adalah: "Pengkhususan seseorang terhadap suatu benda yang memungkinkannya untuk bertindak hukum terhadap benda itu (sesuai 
dengan keinginannya), selama tidak ada halangan syara'. ${ }^{21}$ Dengan demikian kepemilikan berarti: " kepemilikan harta yang didasarkan pada agama". Kepemilikan ini tidak memberikan hak mutlak kepada manusia untuk mempergunakan semaunya, melainkan harus sesuai dengan aturan syara' sebagai batasan normative yang prinsipil. $\mathrm{H}$ al ini mengapresiasikan beberapa prinsip dasar hak milik dalam Islam yang secara garis besar adalah: (a) Pemilik mutlak (the absolute owner) alam semesta ini adalah Allah swt. O leh karena itu pemanfaatan dan pengelolaan alam semesta secara mutlak harus tunduk dengan ketentuan yang digariskan oleh Allah swt. $^{22}$ (b) Manusia diberikan milik terbatas (limited ownership) oleh Allah atas alam semesta, di mana batasan kepemilikan dan cara pemanfaatannya telah ditentukanN ya. $\mathrm{H}$ al ini mengandung konsekuensi bahwa: Pertama, hak milik bukan merupakan suatu yang permanen atau berlaku selamanya secara mutlak tetapi hak milik dapat berubah sesuai dengan ketentuan perubahan yang diatur oleh syara'. Kedua, dalam hak milik terdapat pula kewajiban-kewajiban yang harus ditunaikan. Di mana antara hak dan kewajiban merupakan sebuah konsekuensi logis, sehingga keduanya harus dilakukan. (c) Pada dasarnya Allah menciptakan alam semesta bukan untuk dirin ya sendiri, melainkan untuk kepentingan sarana hidup (wasilah al-hayâh) bagi seluruh makhluk (alam semesta dan isinya) agar tercapai kemakmuran dan kesejahteraan. ${ }^{23}$ (d) M anusia harus mempertanggungjawabkan penggunaan hak milik terbatas ini kepada Allah swt kelak di akhirat.

\section{M acam-M acam Kepemilikan}

Klasifikasi kepemilikan secara global dipetakan menjadi tiga kelompok besar yaitu kepemilikan individu, kolektif dan negara:

1. Kepemilikan Individu (al-milkiyyah al-fardiyyah/private property)

Kepemilikan individu ialah kekayaan yang dapat dimiliki oleh setiap individu masyarakat melalui sebab-sebab kepemilikan yang disyariatkan oleh Allah seperti hak hasil bekerja, waris, dan pemberian harta negara kepada rakyatnya. Kepemilikan pribadi adalah ketentuan hukum syara' yang berlaku bagi zat ataupun kegunaan tertentu, yang memungkinkan pemiliknya untuk memanfaatkan barang tersebut,

\footnotetext{
${ }^{21}$ W ahbah al-Zuhaily, al-Fiqh al-Islâmiy wa A dilatuhu, Juz.4, 57.

22 Lihat Q S. Ali Imran: 189 dan Q S. Al-Mulk: 1-2.

${ }^{23}$ Lihat Q S. al-Baqarah: 29 dan Q S. al-Lukman: 20.
} 
serta memperoleh kompensasinya, baik karena diambil kegunaannya oleh orang lain seperti disewa ataupun karena dikonsumsi dari barang tersebut. ${ }^{24}$ I bnu Taimiyah memberikan penghargaan tinggi atas hak Individu dalam kegiatan ekonomi, meskipun juga menegaskan batasan-batasannya, yaitu tidak bertentangan dengan syariat Islam dan tidak menimbulkan kerugian, baik bagi dirinya maupun orang lain, sehingga tidak terjadi konflik kepentingan. ${ }^{25}$

2. Kepemilikan U mum (al-milkiyyah al-'âmmah/public property)

Kepemilikan umum yaitu ijin syara' kepada suatu masyarakat untuk bersama-sama memanfaatkan suatu benda. Kepemilikan umum dimungkinkan dalam Islam jika suatu benda pemanfaatannya diperuntukan bagi masyarakat umum di mana masing-masing saling membutuhkan. Sektor ini mencakup segala milik umum seperti hasil tambang, minyak, gas, listrik, hasil hutan, air dan sebagainya. Jenis harta ini dijelaskan dalam hadith nabi yang berkaitan dengan sarana umum:

$M$ anusia berserikat (bersama-sama memiliki) dalam tiga hal: air, padang rumput dan api. (HR Ahmad dan Abu Dawud) dan dalam hadith lain terdapat tambahan: "...dan harganya haram" (H R Ibn M ajah dari Ibn Abbas). ${ }^{26}$

Air yang dimaksudkan dalam hadis di atas adalah air yang masih belum diambil, baik yang keluar dari mata air, sumur, maupun yang mengalir di sungai atau danau bukan air yang dimiliki oleh perorangan di rimahnya. O leh karena itu pembahasan para fuqaha mengenai air sebagai kepemilikan umum difokuskan pada air-air yang belum diambil tersebut. ${ }^{27}$ Adapun al-kala' adalah padang rumput, baik rumput basah atau hijau (al-kala') maupun rumput kering (alhasyîsy) yang tumbuh di tanah, gunung atau aliran sungai yang tidak ada pemiliknya. ${ }^{28}$ Sedangkan yang dimaksud al-nâr adalah bahan bakar, sumber energi dan segala sesuatu yang terkait dengannya, termasuk di dalamnya adalah kayu bakar, minyak bumi. ${ }^{29}$

${ }^{24}$ Taqiyuddin An-Nabhani, Membangun Sistem Ekonomi Alternatif Perspektif Islam (Surabaya: Risalah Gusti, 2000), 68.

${ }^{25}$ M .B. Hendrie Anto, Pengantar Ekonomika M ikro Islami (Yogyakarta: Ekonisia, 2003), 103.

${ }^{26}$ al-Syawkani, Nayl al-A wthâr (Beirut: Dar al-Fikr, 1994), jil. 6, 48.

${ }^{27}$ Al-M awardi, al-A hkâm al-Sulthâniyyah wa al-W ilâyah al-Dîniyyah (Beirut: Dar al-Fikr, 1960), 180 184.

${ }^{28}$ Shawkani, Nayl al-A wthâr, jil. 6, 49.

${ }^{29} \mathrm{Abd}$ al-Rahman al-M aliki, Politik Ekonomi Islam, terj. Ibn Sholah (Bangil: al-Izzah, 2001), 91. 
Bentuk kepemilikan umum, tidak hanya terbatas pada tiga macam benda tersebut saja melainkan juga mencakup segala sesuatu yang diperlukan oleh masyarakat dan jika tidak terpenuhi, dapat menyebabkan perpecahan dan persengketaan.

Jika kepemilikan individu, tabiat dan asal pembentukannya tidak menghalangi seseorang untuk memilikinya, maka jenis kepemilikan umum ini, secara tabiat dan asal pembentukannya, menghalangi seseorang untuk memilikinya secara pribadi. Sebagaimana hadis nabi:

Kota M ina menjadi tempat mukim siapa saja yang lebih dahulu (sampai kepadanya)" (H R al-T irmidhi, ibn M ajah, dan al-H akim dari 'Aishah). ${ }^{30}$

$M$ ina adalah sebuah nama tempat yang terletak di luar kota M akkah al-M ukarramah sebagai tempat singgah jama'ah haji setelah menyelesaikan wukuf di padang Arafah dengan tujuan melaksanakan syiar ibadah haji yang waktunya sudah ditentukan, seperti melempar jumrah, menyembelih hewan hadd, memotong qurban, dan bermalam di sana. Makna "munakh man sabaq" (tempat mukim orang yang lebih dahulu sampai) dalam lafad hadis tersebut adalah bahwa M ina merupakan tempat seluruh kaum muslimin. Barang siapa yang lebih dahulu sampai di bagian tempat di M ina dan ia menempatinya, maka bagian itu adalah bagiannya dan bukan merupakan milik perorangan sehingga orang lain tidak boleh memilikinya (menempatinya).

Demikian juga jalan umum, manusia berhak lalu lalang di atasnya. Oleh karenanya, penggunaan jalan yang dapat merugikan orang lain yang membutuhkan, tidak boleh diizinkan oleh penguasa. ${ }^{31}$ Termasuk dalam kategori ini adalah kereta api, instalasi air dan listrik, tiang-tiang penyangga listrik, saluran air dan pipapipanya, semuanya adalah milik umum sesuai dengan status jalan umum itu sendiri sebagai milik umum, sehingga ia tidak boleh dimiliki secara pribadi.32. Barang tambang yang depositnya tidak terbatas juga termasuk sumber daya alam yang menjadi aset publik. sebagaimana hadis nabi riwayat Abu Dawud tentang Abyad ibn

\footnotetext{
${ }^{30}$ al-Suyutiy, al-Jâmi' al-Shaghîr, jil 2, 183.

${ }^{31}$ Abu Ya'la al-Farra', al-A hkâm al-Sulthâniyyah (Beirut: Dar al-Fikr, t.t), 253.

32 Taqiyyud din al-N abhani, al-N izâm al-Iq tishâd fî al-Islâm (Beirut: Dar al-U mmah, 1990), 182.
} 
$\mathrm{H}$ amal yang meminta kepada Rasulullah agar dia diizinkan mengelola tambang garam di daerah $\mathrm{M}$ a'rab:

Bahwa ia datang kepada Rasulullah saw meminta (tambang) garam, maka beliaupun memberikannya. Setelah ia pergi, ada seorang laki-laki yang bertanya kepada beliau: "Wahai Rasulullah, tahukah apa yang engkau berikan kepadanya? Sesungguhnya engkau telah memberikan sesuatu yang bagaikan air mengalir". Lalu ia berkata: Kemudian Rasulullah pun menarik kembali tambang itu darinya" (HR Abu Dawud) ${ }^{33}$.

Larangan tersebut tidak hanya terbatas pada tambang garam saja, melainkan meliputi seluruh barang tambang yang jumlah depositnya banyak (laksana air mengalir) atau tidak terbatas. Ini juga mencakup kepemilikan semua jenis tambang, baik yang tampak di permukaan bumi seperti garam, batu mulia atau tambang yang berada dalam perut bumi seperti tambang emas, perak, besi, tembaga, minyak, timah dan sejenisnya. ${ }^{34}$

Barang tambang semacam ini menjadi milik umum sehingga tidak boleh dimiliki oleh perorangan atau beberapa orang. D emikian juga tidak boleh hukumnya, memberikan keistimewaan kepada seseorang atau lembaga tertentu untuk mengeksploitasinya tetapi pewnguasa wajib membiarkannya sebagai milik umum bagi seluruh rakyat. Negaralah yang wajib menggalinya, memisahkannya dari benda-benda lain, menjualnya dan menyimpan hasilnya di bayt almâl. Sedangkan barang tambang yang depositnya tergolong kecil atau sangat terbatas, dapat dimiliki oleh perseorangan atau perserikatan. $\mathrm{H}$ al ini didasarkan kepada hadis nabi yang mengizinkan kepada Bilal ibn $\mathrm{H}$ arith al-Muzani memiliki barang tambang yang sudah ada dibagian $\mathrm{N}$ ajd dan Tihamah. $\mathrm{H}$ anya saja mereka wajib membayar khumus (seperlima) dari yang diproduksinya kepada bayt al-mâl. ${ }^{35}$

3. Kepemilikan N egara (milkiyyah al-dawlah/state property)

Adalah harta yang merupakan hak bagi seluruh rakyat dan pengelolaannya menjadi wewenang negara, di mana negara berhak memberikan atau mengkhususkannya kepada sebagian rakyat sesuai dengan ijtihadnya. $M$ akna pengelolaan oleh negara ini adalah adanya

\footnotetext{
${ }^{33}$ al-Syawkani, Nayl al-A wthâr, jil. 6, 53.

${ }^{34} \mathrm{Al}$-M aliki, Politik Islam, 80.

35 'Abd al-Q adim Zallum, al-Amwâl fî Dawlah al-Khilâfah (Beirut: Dar al-'Ilm li al- Malayin, 1983), 89.
} 
kekuasaan yang dimiliki pemerintah untuk mengelolanya. ${ }^{36}$ Kepemilikan negara ini meliputi semua jenis harta benda yang tidak dapat digolongkan ke dalam jenis harta milik umum (al-milkiyyah al'âmmah/public property) namun terkadang bisa tergolong dalam jenis harta kepemilikan individu (al-milkiyyah al-fardiyyah).

$\mathrm{H}$ arta milik negara pada dasarnya juga merupakan hak milik umum, tetapi hak pengelolaannya menjadi wewenang pemerintah. $\mathrm{N}$ amun demikian, cakupan keumuman hak milik yang dapat dikuasai oleh pemerintah ini lebih luas daripada sekedar hak umum dalam penjelasan di atas atau lebih tepatnya hak seluruh rakyat dalam suatu negara yang wewenang pengelolaannya ada di tangan pemerintah. Berbeda dengan hak milik umum, hak milik negara ini dapat dialihkan menjadi milik individu jika memang kebijakan negara demi kemaslahatan yang lebih luas. ${ }^{37}$

$\mathrm{H}$ arta yang dapat dikategorikan ke dalam jenis kepemilikan negara misalnya: ghanîmah, kharâj, temuan benda tak bertuan, pajak atau penerimaan lain yang diperoleh dari Badan U saha milik N egara (BU M N ). N egara juga memiliki hak terhadap berbagai barang dan jasa di luar yang dimiliki individu dan milik umum, terutama yang terkait untuk memperoleh penghasilan dan kekuasaan untuk melaksanakan kewajibannya. U ntuk menyelenggarakan pendidikan, penyediaan fasilitas publik, memelihara hukum dan keadilan, menyantuni fakir miskin dan lainnya, negara dapat memungut pajak secara terbatas kepada masyarakatnya di samping mengandalkan pemasukan yang lain.

\section{H ak Pemanfaatan Sumber D aya Alam dalam Islam}

Sumber daya alam adalah dalam pengertian umum didefenisikan sebagai suatu yang dipandang memiliki nilai ekonomi. Dapat juga dikatakan bahwa sumber daya alam adalah komponen dari ekosistem yang menyediakan barang dan jasa yang bermanfaat bagi kebutuhan manusia. ${ }^{38}$ Slamet Riyadi mendefinisikan sumber daya alam sebagai segala isi yang terkandung dalam biosfer, sebagai sumber energi yang potensial, baik yang tersembunyi di dalam litosfer (tanah), hidrosfer (air)

\footnotetext{
${ }^{36}$ Al-N abhani, al-Nizâm al-lq tishâdiy, 218.

${ }^{37}$ M.B. Hendrie Anto, Pengantar Ekonomika M ikro Islami (Yogyakarta: Ekonisia, 2003),110-111.

${ }^{38}$ Ulfah Utami, Konservasi Sumber Daya Alam (Malang: UIN M alang press, 2008), 6.
} 
maupun atmosfer (udara) yang dapat dimanfaatkan untuk pemenuhan kebutuhan manusia secara langsung maupun tidak langsung. Herman $\mathrm{H}$ aeruman Js menyatakan bahwa: Sumber daya alam adalah sumber daya yang terbentuk karena kekuatan alami misalnya tanah, air dan perairan, biodata, udara dan ruang, mineral, bentang alam (landscape), panas bumi dan gas bumi, angin, pasang surut dan arus laut. Jadi sumber daya alam adalah segala sesuatu yang ada di sekeliling manusia yang bukan dibuat manusia, dan yang terdapat di permukaan bumi, baik itu berada di dalam tanah, laut ataupun air dan di udara, yang dapat dimanfaatkan untuk pemenuhan kebutuhan manusia maupun organisme lain secara langsung maupun tidak langsung. ${ }^{39}$

Sumber daya alam seperti air, udara, lahan minyak, ikan hutan, dan lain-lain merupakan sumber daya yang esensial bagi kelangsungan hidup manusia. H ilangnya atau berkurangnya ketersedian sumber daya alam seperti tercemarnya air sehingga susah mendapatkan air bersih, rusaknya lahan karena pertambangan akan berdampak besar pada kelangsungan hidup manusia di bumi ini. Pengelolaan sumber daya alam yang baik akan meningkatkan kesejahteraan umat manusia, namun sebaliknya pengelolaan sumber daya alam yang tidak baik akan berdampak buruk bagi lingkungan hidup. O leh karena itu, persoalan mendasar dalam pengelolan sumber daya alam adalah bagaimana mengelola sumber daya alam tersebut agar mendatangkan manfaat yang sebesar-besarnya bagi manusia dengan tidak mengorbankan lingkungan hidup maupun kelestarian sumber daya alam itu sendiri. ${ }^{40}$ Sebagaimana telah dinyatakan dalam al-Q ur'an bahwa sumber daya alam yang ada dibumi ditujukan untuk kemakmuran manusia sebagai khalifatullah untuk mengelola dan memanfaatkannya tanpa merusak tatanan yang telah ada. ${ }^{41}$

"dan D ia lah yang menjadikan kamu penguasa-penguasa di bumi dan Dia meninggikan sebahagian kamu atas sebahagian (yang lain) beberapa derajat, untuk mengujimu tentang apa yang diberikan-N ya kepadamu. Sesungguhnya Tuhanmu amat cepat siksaan- $N$ ya dan sesungguhnya $D$ ia $M$ aha Pengampun lagi $M$ aha Penyayang"

\footnotetext{
${ }^{39}$ lbid., 9.

${ }^{40}$ A khmad Fauzi, Ekonomi Sumber Daya Alam dan Lingkungan (Jakarta: Gramedia, 2010), 2.

${ }^{41}$ QS. Al- An'am: 165,
} 
Alam memang diciptakan oleh Allah untuk manusia, ${ }^{42}$ termasuk segala sumber dayanya, baik yang terpendam di dalam tanah, di laut, di udara maupun yang terhampar di permukaan bumi. ${ }^{43}$ Adalah hak manusia untuk memanfaatkan segala sumber daya tersebut, akan tetapi dia juga harus ingat bahwa selain untuk memenuhi kebutuhan hidupnya alam diciptakan oleh Allah sebagai suatu bentuk pelajaran yang dengan pelajaran itulah manusia akan lebih mengenal Tuhannya.

Pemanfaatan sumber daya alam yang ada di alam ini harus dikelola dengan mempertimbangkan kelestarian lingkungan, artinya memanfaatkan sumber daya alam seperlunya dengan tidak mengeksploitasi yang bisa menyebabkan kerusakan lingkungan. Di samping itu manusia juga memiliki kewajiban yang harus dipenuhinya, yaitu menjaga keserasian dan keseimbangan ekosistem dan tidak membuat kerusakan-kerusakan, baik terhadap binatang, tumbuhtumbuhan maupun jenis-jenis makhluk lain kecuali jika memang dia menobatkan dirinya sebagai manusia munafik yang tercela. ${ }^{44}$

Pemanfaatan sumber daya alam menurut al-Qur'an berdasarkan materinya diklasifikasikan sebagai berikut:

1. Pemanfaatan Sumber D aya Laut

Laut merupakan salah satu bagian dari wilayah bumi yang dianugerahkan oleh Allah kepada manusia yang di dalamnya mengandung aneka sumber daya laut yang sangat bernilai untuk dieksplorasi, dikelola, dan dimanfaatkan seoptimal mungkin demi memenuhi kebutuhan hidup dan kesejahteraan masyarakat. Laut sebagai aset publik yang tidak bisa dikuasai oleh individu. Oleh karena itu membutuhkan peran negara dalam pengelolaan potensi kelautan sehingga dapat menopang perekonomian nasional. Ragam pemanfaatan potensi laut sebagaimana diinformasikan dalam ayatayat al-Q ur'an tentang ragam potensi sumber daya laut, di antaranya yaitu: Sebagai sumber pangan ${ }^{45}$ sumber energi ${ }^{46}$ tambang, mineral dan sebagai sarana transportasi. ${ }^{47}$

\footnotetext{
${ }^{42}$ Q S. Al-Baqarah: 38.

${ }^{43}$ Q S. 16 Ayat: 5-14; dan Q S. 57 Ayat: 25.

${ }^{44}$ Q S. Al-Baqarah: 205.

${ }^{45}$ Q S. al-M a'idah:96

${ }^{46} \mathrm{Q}$ S. at-Thur ayat: 6

${ }^{47}$ Q S. Al Isra': 66
} 


\section{Pemanfaatan Sumber D aya Air}

Air sebagai sumber kehidupan menjadi kebutuhan pokok manusia, tanpa air manusia, hewan dan tumbuhan tidak bisa bertahan hidup karena air adalah materi yang paling vital dalam kehidupan semua mahluk. Manfaat air secara garis besar bisa dikelompokan menjadi empat bagian, yaitu:

Pertama, air digunakan untuk bersuci dan kebutuhan kebersihan. Al-Qu r ' à $\mathrm{n}$ me $\mathrm{n} \mathrm{y} \mathrm{e} \mathrm{b} \mathrm{u} \mathrm{t} \mathrm{k} \mathrm{a} \mathrm{n}$ ma nf a a $\mathrm{t}$ a bersuci dalam surat al-Anfal (8) ayat 11 . Bersuci dalam ayat ini bisa dipahami dalam arti umum dan agamis. Bersuci dalam arti umum yaitu dimanfaatkan untuk membersihkan diri, mandi, mencuci pakaian, dan membersihkan benda-benda lahiriyah yang terlihat kotor, sedangkan dalam arti agamis air bisa membersihkan jiwa dan kekotoran jiwa batin dengan wudhu dan mandi junub. ${ }^{48}$

Kedua, air dimanfaatkan untuk memenuhi kebutuhan pokok makhluk hidup (manusia, hewan, dan tumbuhan). Dalam surat alFurqan (25) ayat 49:

Agar Kami menghidupkan dengan air itu negeri (tanah) yang mati, dan agar Kami memberi minum dengan air itu sebagian besar dari makhluk Kami, binatang-binatang ternak dan manusia yang banyak.

Ketiga, air sebagai sarana irigasi untuk mengairi lahan pertanian. Selain untuk memenuhi kebutuhan bersuci dan minum manusia dan makhluk hidup air juga berperan penting dalam ketahanan pangan pertanian. Tanpa air tak akan ada tumbuhan dan buah-buahan karena unsur paling urgen dari ketahanan pangan adalah air dan tanah. D alam al-Q u r ' $\bar{a}$ n $\quad s$ u atyat 32 dinyatakanabthwa rair adalah sumber kehidupan tumbuhan dan kesuburan tanah:

Allah-lah yang telah menciptakan langit dan bumi dan menurunkan air hujan dari langit, kemudian $\mathrm{D}$ ia mengeluarkan dengan air hujan itu berbagai buah-buahan menjadi rezeki untukmu; dan Dia telah menundukkan bahtera bagimu supaya bahtera itu, berlayar di lautan dengan kehendak- $\mathrm{N}$ ya, dan Dia telah menundukkan (pula) bagimu sungai-sungai. ${ }^{49}$

\footnotetext{
48 Kementerian agama RI. Tafsir Al-Q ur'an Tematik Pelestarian Lingkungan Hidup (Jakarta: PT. Sinergi Pustaka Ind onesia, 2009), 89.

${ }^{49}$ Kementerian A gama, al-Q ur'an dan Terjemahnya.,
} 
Keempat, pemanfaatan air sebagai sumber energi. Air bisa dimanfaatkan untuk menghasilkan energi listrik. Sumber daya air menyediakan berbagai manfaat yang dibutuhkan oleh masyarakat jika dikelola dengan baik. Seperti halnya Daerah Aliran Sungai (DAS) Brantas yang banyak dimanfaatkan oleh masyarakat untuk menambang pasir. M enurut Peraturan Pemerintah N 0. 37 tahun 2012 tentang pengelolaan D aerah Aliran Sungai (D AS), D AS adalah suatu wilayah daratan yang merupakan satu kesatuan dengan sungai dan anak-anak sungainya, yang berfungsi menampung, menyimpan dan mengalirkan air yang berasal dari curah hujan ke danau atau ke laut secara alami, yang batas di darat merupakan pemisah topografis dan batas di laut sampai dengan daerah perairan yang masih terpengaruh aktivitas daratan. Bentuk DAS akan mempengaruhi debit pengaliran, pola banjir dan debit banjir.

Berdasarkan peraturan pemerintah No 27 T ahun 1980, mineral (bahan galian) diklasifikasikan menjadi 3 golongan yakni:

(1) Golongan bahan galian yang strategis (A) adalah: minyak bumi, bitumen cair, lilin bumi, gas alam; bitumen padat, aspal; antrasit, batu bara, batu bara muda; uranium, radium, thorium dan bahanbahan galian radioaktif lainnya; nikel, koblat dan timah.

(2) Golongan bahan galian yang vital (B) adalah: besi, mangan, molobden, khrom, wolfram, vanadium, titan; bauksit, tembaga, timbal, seng; emas, platina, perak, air raksa, intan; arsenm antimony, bismut; yttrium, rhutenium, cerium, dan logam-logam langka lainnya; berillium, korundum; zircon, kristal kwarsa; kriolit, fluorspar, barit; yodium, brom, klor dan belerang. Golongan bahan galian yang tidak termasuk golongan A atau B adalah: nitrat, pospat, garam batu (halite); asbes, talk, mika, grafit, magnesit; yarosit, leusit, tawas, oker; batu permata, batu setengah permata; pasir kwarsa, kaolin, felspar, gips, bentonit; batu apung, tras, obsidian, perlit, tanah diatome, tanah serap; marmer, batu tulis; batu kapur, dolomit, kalsit; granit, andesit, basal, trakhit, tanah liat dan pasir sepanjang tidak mengandung unsur-unsur golongan A maupun B dalam jumlah yang berarti ditinjau dari segi ekonomi pertambangan.

M enurut Peraturan Daerah Provinsi Jawa Timur Nomor 1 Tahun 2005 pertambangan bahan galian golongan C di sungai 
dan kantong-kantong pasir yang selanjutnya disebut pertambangan adalah usaha pengambilan bahan galian golongan $\mathrm{C}$ di sungai. Bahan galian $\mathrm{C}$ di sungai adalah bahan galian yang berupa pasir, kerikil dan batu yang ditambang dari sungai.

3. M anfaat Sumber $D$ aya Angin

Dalam al-Qur'an angin adalah udara yang bergerak akibat adanya perbedaan tekanan udara dengan arah aliran angin dari tempat yang bertekanan rendah atau dari daerah yang memiliki suhu/temperatur ke wilayah bersuhu tinggi..$^{50}$ Beberapa manfaat udara dijelaskan dalam al-Q ur'an di antaranya;

Pertama, angin sebagai salah satu sumber energi. Al-Q ur'an telah menjelaskan dalam surat Saba' (34) ayat 12. D alam ayat ini dijelaskan bahwa pada zaman nabi Sulaiman angin telah menjadi salah satu sumber daya alam untuk sumber energi yang bisa menggerakkan kapal yang berlayar dilautan. D engan bantuan energi angin yang menggerakan kapal Sulaiman bisa membantu mempersingkat waktu tempuh perjalanan yang dibutuhkan jika ditempuh dengan jalur darat dengan unta kala itu. ${ }^{51} \mathrm{D}$ alam masa modern sumber daya angin sebagai energi bisa dimanfaatkan sebagai tenaga pembangkit listrik yang dikenal dengan istilah PLTA, dengan bantuan turbin-turbin yang berputar karena daya angin. ${ }^{52}$

Kedua, angin bermanfat sebagai pembibit alami. Artinya adalah angin bisa melakukan penserbukan tanamaan dengan alami tanpa bantuan manusia, dan mengawinkan satu bibit tanaman dengan tanaman lain yang bermanfaat untuk manusia tanpa manusia bantuan tangan manusia. $\mathrm{H}$ al ini disebutkan dalam surat al-H ijr (15) ayat 22: $\mathrm{D}$ an Kami telah meniupkan angin untuk mengawinkan (tumbuhtumbuhan) dan Kami turunkan hujan dari langit, lalu Kami beri minum kamu dengan air itu, dan sekali-kali bukanlah kamu yang menyimpannya.

4. M anfaat Sumber D aya Flora dan Vegetasi

Tumbuhan dan pepohonan merupakan penghuni bumi pertama dalam sejarah penemuan manusia, ahli sejarah memperkirakan bahwa pepohonan dan tumbuhan telah ada jauh sebelum adanya manusia

\footnotetext{
${ }^{50}$ Kementerian A gama RI. T afsir Al-Q ur'an Tematik Pelestarian Lingkungan Hidup,100.

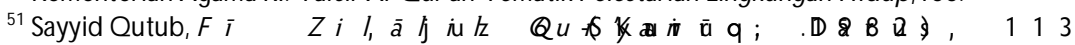

${ }^{52}$ Muhammad Manshur Hasbunnab'i, Ar-Riyâh Ni'mah wa Niqmah ( $\mathrm{K}$ a i $r$ o-Fikr, 199ä)r86. A l
} 
dan hewan. Dari sekian banyak ayat yang berbicara tentang tumbuhan dan pepohonan, dapat dikategorikan bahwa manfaat tumbuhan dan pepohonan secara umum dalam al-Q $\mathrm{u} \mathrm{r}^{\prime} \overline{\mathrm{a}} \mathrm{n}$ yaitu:

Pertama, tumbuhan sebagai sumber makanan. $\mathrm{H}$ al ini terdapat dalam surat 'Abasa (80) ayat 24-32. Dalam ayat ini digambarkan bahwa tumbuhan dan pepohan dimanfaatkan sebagai sumber makanan nabati bagi manusia, jika Jika diartikan dalam makna yang luas dapat diartikan bahwa manfaat aneka vegetasi dan pepohonan di samping untuk kepentingan makanan secara langsung juga dapat mendatangkan manfaat lain dengan mengolahnya menjadi barang yang dibutuhkan manusia sehingga mennghasilkan uang yang bisa dipergunakan untuk kesenangan hidup lainnya. Artinya tumbuhan dan pepohonan bisa diolah menjadi benda lain seperti kertas, kursi dan benda-benda kebetuhan sekunder manusia

Kedua, tumbuhan dimanfaatkan untuk dijadikan obat-obatan. Dari beberapa jenis tumbuahn dan buah-buahan yang disebutkan dalam al-Qur'an bisa dimanfaatkan sebagai obat yang berkhasiat untuk kesehatan tubuh manusia. $M$ anfaat tumbuhan sebagai obatobatan tergambar dalam surat an- $\mathrm{N}$ ahl (16) ayat 69:

Ketiga, tumbuhan bermanfaat sebagai produsen oksigen yang melapisi atmosfer di bumi sehingga layak dihuni oleh mahluk hidup. ${ }^{53} \mathrm{H}$ al ini mengungkap hikmah di balik penciptaan tumbuhan sebagai makhluk hidup pertama yang ada dibumi, setelah itu diikuti dengan manusia dan hewan.

5. Pemanfaatan Sumber D aya Fauna

Pemanfaatan binatang sebagai sumber daya alam secara umum tergambar dalam Q S. Ali Imran (3) ayat 14. D alam ayat ini dijelaskan bahwa binatang ternak merupakan kesenangan hidup dunia seperti halnya kesenangan hidup dunia lainnya. Kesenangan dunia ini bisa dipahami dalam beberapa bentuk pemanfaatan binatang sebagai sumber daya, seperti binatang dimanfaatkan untuk alat transportasi contohnya kuda, unta, keledai, ini terdapat dalam suratan al-N ahl (16) ayat 7 , dan ada juga yang dimanfaatkan untuk dikonsumsi dagingnya dan susunya seperti dalam surat an- $\mathrm{N}$ ahl (16) ayat 5.

${ }^{53}$ Jamaludd in Husein Mahran, An-N abâtât fi al-Q ur'ân al-Karîm (Kairo: Kementrian W akaf M esir, 2000), 155. 
Selain dari dua hal tersebut, binatang sebagai sumber daya mempunyai peran yang sangat penting dalam kelangsungan hidup di bumi seperti halnya tumbuhan, karena binatang merupakan unsur penting dalam rantai makanan. Jika binatang punah maka salah satu unsur rantai makanan terputus dan terjadi ketidak seimbangan dalam kehidupan bumi.

\section{Konservasi Sumber D aya Alam}

Islam mempunyai ketentuan mengenai perlindungan alam dan termasuk dalam syariat. Di dalam Islam di kenal istilah himâ' yaitu suatu kawasan yang khusus dilindungi oleh pemerintah (I mam negara atau khalifah) atas dasar syariat guna melestarikan alam baik hutan maupun lautan. Konservasi ini dimaksudkan untuk mencegah kerusakan alam karena ulah manusia yang serakah dalam memanfaatkan sumber daya yang ada. Sifat serakah manusia pada materi mempunyai dampak luas pada kualitas lingkungan, ketika aturan dan system tidak lagi diperhatian maka manusia di alam dapat menjadi top predator yang mempengaruhi sistem kehidupan.

Salah satu cara yang praktis adalah dengan mengatur pola konsumsi manusia. Pola konsumsi manusia dalam skala besar maupun kecil dapat mempengaruhi kelestatian lingkungan hidup, tidak terkecuali karena perilaku konsumtif manusia yang merambah hutan maupun laut tanpa memikirkan kelestariannya, perilaku seperti ini akan mempengaruhi kepunahan flora dan fauna yang menjadi buruan. M aka untuk menjaga kelestarian alam adalah dengan membatasi konsumsi atau membatasi penangkapan ikan berlebihan (overfishing). Pola konsumsi yang telah ditetapkan syariat, merupakan legitimasi kuat ajaran Islam yang menyatukan perilaku keseharian ummat sebagai ibadah yang oleh fuqaha (ahli hukum I slam) digolongkan dalam urusan 'ubûdiyyah. ${ }^{54}$

M emanfaatkan sumber alam jika dilakukan dengan benar tanpa membuat kerusakan adalah ibadah sebagai manifestasi atas perintah Allah kepada manusia untuk berusaha mencari rizki guna memenuhi kebutuhan hidup agar menjadi sejahtera. Aktifitas ini tidak boleh dilakukan secara eksploitatif, hanya menguras sumber daya alam dan mencemari lingkungan, sebab akan menimbulkan kerusakan pada

\footnotetext{
${ }^{54}$ Fachruddin M. Mangunjaya, Konservasi Alam dalam Islam (Jakarta: Yayasan O bor Indonesia, 2005), 42.
} 
ekologi. Allah swt. menyatakan kemurkaan-N ya kepada para pelaku perusakan di bumi (alam), agar mereka ditangkap untuk dibunuh dan disalib, supaya kejahatan tidak merajalela sebagaimana Allah tegaskan dalam Q S. al-M aidah ayat 33-34:

Sesungguhnya pembalasan terhadap orang-orang yang memerangi Allah dan Rasul-N ya dan membuat kerusakan di muka bumi, hanyalah mereka dibunuh atau disalib, atau dipotong tangan dan kaki mereka dengan bertimbal balik, atau dibuang dari negeri (tempat kediamannya). Yang demikian itu (sebagai) suatu penghinaan untuk mereka di dunia, dan di akhirat mereka beroleh siksaan yang besar, kecuali orang-orang yang tobat (di antara mereka) sebelum kamu dapat menguasai (menangkap) mereka; maka ketahuilah bahwasanya Allah $\mathrm{M}$ aha Pengampun lagi $\mathrm{M}$ aha Penyayang. ${ }^{55}$

Ancaman-ancaman di atas tampaknya sangat relevan jika ditujukan pula kepada para perusak lingkungan, baik di darat maupun di laut, seperti para pelaku tindak illegal logging (pencurian kayu) di hutan, para pencuri ikan (illegal fishing) yang dilakukan nelayan asing, serta pencurian pasir laut di perairan laut Indonesia, dan lain-lain. Ancaman dengan hukum bunuh dan disalib tersebut cukup masuk akal, oleh karena tindak kejahatan mereka seperti disebutkan di atas pada dasarnya merusak ekosistem lingkungan di darat dan di laut, di mana hal ini dapat membahayakan kelestarian lingkungan yang pada akhirnya dapat mendatangkan bencana alam. ${ }^{56}$

Menurut Yusuf Q ardhawi, melestarikan lingkungan merupakan upaya untuk menciptakan kemaslahatan dan mencegah kemudharatan. $\mathrm{H}$ al ini sejalan dengan maqâshid al-syarî'ah (tujuan syariat agama) yang terumuskan dalam kulliyât al-khams, yaitu: hifzu al-dîn (melindungi agama), hifz al-nafs (melindungi jiwa), hifz al-'aql (melindungi akal), hifz al-nasab (melindungi keturunan) dan hifz al-mâl (melindungi kekayaan/property). M enjaga kelestarian lingkungan hidup menurutnya merupakan tuntutan untuk melindungi kelima tujuan syariat tersebut. D engan demikian, segala perilaku yang mengarah kepada pengrusakan lingkungan hidup semakna dengan perbuatan mengancam agama, jiwa,

\footnotetext{
${ }^{55}$ Departemen Agama RI., AI Q ur'an ..., . 164

${ }^{56}$ A hmad Yusam Thobroni, Fikih Kelautan. (Jakarta: Dian Rakyat, 2011), 167
} 
akal, nasab, dan harta. ${ }^{57} \mathrm{D}$ alam konteks pelestarian lingkungan ini, Yusuf Q ardhawi bahkan menegaskan penerapan hukuman sanksi berupa kurungan (at-ta'zîr) bagi pelaku pengrusakan lingkungan hidup yang ditentukan oleh pemerintah (wali al-amr).

Penguasaan manusia terhadap lingkungannya adalah amanah dari Allah, tidak mutlak dan akan dipertanggungjawabkan kepada-N ya. Sehubungan dengan pengelolaan sumber daya tersebut, Islam mengatur hal-hal sebagai berikut:

1. Tidak membuat kerusakan di bumi

Banyak ayat dalam al-Qur'an yang menegaskan, agar manusia tidak membuat kerusakan di muka bumi. Suatu sikap manusia yang sejak semula telah dikhawatirkan oleh para malaikat. ${ }^{58}$ Bentuk-bentuk kerusakan ini menurut ilmu lingkungan bisa muncul dalam bermacam-macam aktivitas seperti menggunakan sumber daya alam yang melebihi maximum sustained yield, memutuskan salah satu mata rantai dalam food-chains atau web of life, mengeksploitasi daur materi, dan menghasilkan berbagai macam pencemaran yang akan mengganggu stabilitas tata lingkungan. Kerusakan tersebut bisa muncul dalam bentuk aktivitas-aktivitas semacam penumpukan sumber daya alam, eksploitasi sumber daya manusia, pengacauan terhadap keamanan, pelanggaran terhadap ketertiban, pemutusan hubungan saudara, penelantaran terhadap kemiskinan, kelalaian terhadap pendidikan dan keagamaan, dan bentuk-bentuk aktivitas lain yang bisa mengganggu tata lingkungan.

2. Ramah terhadap alam

Islam menganjurkan manusia untuk bersahabat dengan alam karena keberadaan flora dan fauna memberikan manfaat kepada manusia sehingga perlu diimbangi dengan suatu "perilaku" yang baik.

3. Tidak berlaku boros

M enggunakan sumber daya secara berlebihan dan berlaku boros adalah suatu tindakan yang tidak dibenarkan. Bahkan Allah menggolongkan manusia yang berlaku boros sebagai teman/perbuatan setan. D alam ilmu lingkungan pemborosan ini bisa muncul dalam bentuk ketidakseimbangan pertukaran materi dan

\footnotetext{
${ }^{57}$ Yusuf AI-Q ardhawi, Ri'âyah al-Bî ah fi as-Syarî'ah al-Islâmiyyah (Kairo: Dar Al-Syuruq, 2001), 44.

${ }^{58}$ Q S. Al-Baqarah: 30.
} 
transformasi energi, atau pemborosan juga penggunaan sumber daya yang tidak sebanding dengan daya gunanya. Pemborosan adalah suatu bentuk kejahatan tersendiri, karena dengan berbuat boros berarti mengurangi atau bahkan menghilangkan hak dan kesempatan manusia atau makhluk hidup yang lain atas suatu sumber daya.

4. M enjaga kelestarian sumber daya

M enjaga kelestarian alam dapat menjadi amal jariyah sehingga manusia dimungkinkan untuk tetap menerima kebaikan yang mengalir tiada henti-hentinya, meskipun dia telah meninggal. Konsep amal jariyah adalah suatu konsep tentang pembangunan yang tidak hanya bermanfaat bagi dirinya di masa kini dan di akhirat nanti, akan tetapi juga bagi generasi-generasi sesudahnya.

5. M eningkatkan kesejahteraan umum

Islam mengajarkan bahwa kekayaan yang diperoleh seseorang tidak untuk dimiliki sendiri, karena dia mempunyai kewajiban untuk mengeluarkan sebahagaian dari kekayaannya itu untuk diberikan kepada orang-orang yang membutuhkan dan berhak untuk menerimanya. Di samping itu, cara pembelanjaannya pun juga diatur agar manusia tidak sia-sia dalam membelanjakannya. Bentuk-bentuk zakat, infaq dan shadaqah tiada lain adalah upaya pencarian keridoan Tuhan yang dimanifestasikan dalam bentuk peningkatan kesejahteraan umum. D engan cara semacam ini kesenjangan tingkat sosial ekonomi yang bisa menimbulkan gangguan tata lingkungan bisa dikurangi atau bahkan dihilangkan.

\section{Simpulan}

Menurut Hukum Islam, masyarakat memiliki hak untuk memanfaatkan segala sumber daya alam yang telah Allah sediakan untuk menjamin kesejahteraan manusia, karena setiap orang memiliki hak irtifâq yaitu hak pemanfaatan sumber daya, baik yang bersifat privat ataupun publik. $\mathrm{H}$ al ini dimungkinkan karena kepemilikan umum dalam hukum Islam dibolehkan jika suatu aset atau sumber daya pemanfaatannya diperuntukkan bagi masyarakat umum yang mana masing-masing saling membutuhkan. Sektor ini mencakup segala milik umum seperti hasil tambang, minyak, gas, listrik, hasil hutan, air (sumber mata air, sungai, laut) dan sebagainya. $\mathrm{N}$ amun manusia dalam melakukan eksplorasi sumber daya alam tidak boleh mengabaikan 
kelestarian lingkungan yang dapat menimbulkan kerusakan ekologis. Prinsip kebebasan yang diberikan Islam bagi pemilik hak untuk mempergunakan haknya bukanlah bebas tanpa batas. $\mathrm{N}$ amun dibatasi oleh pertanggungjawaban dan kepatuhan pada syariah. Atas dasar prinsip ini pemilik hak dilarang mempergunakan haknya secara berlebihan ta'assul fî isti'mâl al-haq (sewenang-wenang dalam penggunaan hak) yang menimbulkan pelanggaran hak dan kerugian terhadap kepentingan orang lain maupun terhadap hak dan kepentingan masyarakat umum dan dapat dikenai hukuman penjara (ta'zîr) oleh hakim

Pada prinsipnya, Islam memberikan kebebasan bagi setiap pemilik hak untuk mempergunakan haknya sesuai dengan kehendaknya, sepanjang tidak bertentangan dengan syariat Islam. Atas dasar prinsip ini, pemilik hak dilarang mempergunakan haknya untuk hal-hal yang dilarang oleh syara'. H al ini sejalan dengan maqâshid al-syarî'ah (tujuan syariat agama) yang terumuskan dalam kulliyât al-khams, yaitu: hifz aldîn (melindungi agama), hifz al-nafs (melindungi jiwa), hifz al-'aql (melindungi akal), hifz al-nasab (melindungi keturunan) dan hifz al-mâl (melindungi kekayaan/properti). D engan demikian, segala perilaku yang mengarah kepada pengrusakan lingkungan hidup semakna dengan perbuatan mengancam agama, jiwa, akal, nasab, dan harta yang terancam hukuman sanksi berupa kurungan (ta'zîr) bagi pelaku pengrusakan lingkungan hidup yang ditentukan oleh pemerintah (wali al-amr).

\section{D aftar Rujukan}

A. Mas'adi, Ghufron. Fiqh Muamalah Kontekstual. Jakarta: Raja Grafindo Persada, 2002.

Ad-D uraini, Fathi. at-T a'assul fi Isti'mal al-H aq. Beirut: M uassasah arRisalah, 1977.

Ahmad Yusam Thobroni, Fikih Kelautan. Jakarta: D ian Rakyat, 2011.

Al-Kasani, Badâ'i' ash-Shanâi'. Beirut: D ar al-G harb al-Islamiy, t.t.

Al-M aliki, Abd al-Rahman. Politik Ekonomi Islam. terj. Ibn Sholah, Bangil: al-Izzah, 2001.

Al-M awardi. al-Ahkâm al-Sulthâniyyah wa al-Wilâyah al-Dîniyyah. Beirut: D ar al-Fikr, 1960.

Al-N abhani, T aqiyuddin. M embangun Sistem Ekonomi Alternatif Perspektif I slam. Surabaya: Risalah Gusti, 2000. 
. al-N izâm al-Iqtishâd fî al-Islâm. Beirut: Dar al-U mmah, 1990.

Al-Q ardhawi, Yusuf. Ri'âyah al-Bî̀ah fi as-Syarî'ah al-Islâmiyyah. Kairo: Dar al-Syuruq, 2001.

Al-Syawkani. N ayl al-Awthâr. Beirut: D ar al-Fikr, 1994.

Al-Zarqa', M ustafa Ahmad. al-M adkhal al-Fiqh al-Âmm. Beirut: D ar alFikri tt.

As-Sunburi, Abdurrazaq. Mashadirul $\mathrm{H}$ aq fil Fiqhil Islam. t.t.p: Dirasatul Arabiyah, t.t.

D ahuri, Rokhmin. dkk. Pengelolaan Sumber Daya Alam. Jakarta: PT Pradnya Paramita, 2004.

D epartemen Agama. Al-Q ur'an dan T erjemahnya. Jakarta: D epartemen Agama, 1997.

Fauzi, Akhmad. Ekonomi Sumber D aya Alam dan Lingkungan. Jakarta: Gramedia, 2010.

$\mathrm{H}$ endrie Anto, M B. Pengantar Ekonomika M ikro Islami. Yogyakarta: Ekonisia, 2003.

H usein M ahran, Jamaluddin. An-N abâtât fi al-Q ur'ân al-Karîm. Kairo: Kementrian W akaf M esir, 2000.

Kementrian agama RI. Tafsir Al-Q ur'an Tematik Pelestarian Lingkungan H idup. Jakarta: PT. Sinergi Pustaka Indonesia, 2009.

M. M angunjaya, Fachruddin. Konservasi Alam dalam Islam. Jakarta: Yayasan 0 bor Indonesia, 2005.

Manshur Hasbunnab'i, Muhammad. Ar-Riyâh Ni'mah wa Niqmah. Kairo: D ar al-Fikr, 1997.

Q utub, Sayyid. $F \bar{i} \quad Z$ i 1 . Kalro: Dar af

S. Resosoedarmo. dkk. Pengantar Ekologi. Jakarta: Fakulktas Pascasarjana IKIP, 1985.

Shihab, Alwi. Islam Inklusif. Bandung: M izan, 1998.

Soemarwoto, $\mathrm{O}$ tto. Ekologi, Lingkungan Hidup dan Pembangunan. Jakarta: D jambatan, 1997.

U tami, Ulfah. Konservasi Sumber D aya Alam. Malang: UIN M alang press, 2008.

Yafie, Ali. M erintis Fiqih Lingkungan Hidup. Jakarta: UFUK Press, 2006.

Ya'la al-Farra', Abu. al-Ahkâm al-Sulthâniyyah. Beirut: D ar al-Fikr, t.t. 
Zallum, 'Abd al-Q adim. al-Amwâl fî D awlah al-Khilâfah. Beirut: D ar al'Ilm li al- M alayin, 1983. 